\title{
Corporate Sustainability Reporting and Analysis of Sustainability Reports in Turkey
}

\author{
Rabia Aktaş ${ }^{1}$, Koray Kayalidere ${ }^{1} \&$ Mahmut Karğin ${ }^{1}$ \\ ${ }^{1}$ Accounting and Finance Department, Celal Bayar University, Manisa, Turkey \\ Correspondence: Rabia Aktaş, Accounting and Finance Department, Celal Bayar University, Uncubozköy, \\ Manisa, Turkey. Tel: 90-236-233-0657. E-mail: aktas.rabia@yahoo.com
}

Received: December 7, 2012

Accepted: January 22, $2013 \quad$ Online Published: February 22, 2013

doi:10.5539/ijef.v5n3p113

URL: http://dx.doi.org/10.5539/ijef.v5n3p113

Early version of this paper was presented at "First International Conference on Sustainable Business and Transitions for Sustainable Development”, 11-13 October 2012, Konya-Turkey.

\begin{abstract}
Financial reports are the most important sources of information for financial information users. Investors, lenders, and other creditors use financial information in their decision making process. Therefore, governmental bodies of financial reporting have mandated disclosing of some financial reports (statement of financial position, statement of comprehensive income, and statement of changes in equity) for public interest. It has been stated that besides financial information, non-financial information is also important for the users. It is clear that financial information contributes better decisions making when it is supported by non-financial information. Non-financial reports inform stakeholders (e.g., investors, employees, customers, and non-governmental organizations) and the general public about the firm's activities involving environmental, social, and governance (ESG) issues. In this study we have discussed elements of corporate sustainability reporting and detected sustainability reports of selected public firms in Turkey. Sustainability reports of nine firms have been analyzed based on the Global Reporting Initiative (GRI) indicators. The results show that selected firms' sustainability reports fulfill requirements related to Part I and Part II, "Profile Disclosures" and "Disclosures on Management Approach", which is mostly consistent with their reports' application level. However, it is hard to say the same thing for Part III. In fact, firms' sustainability reports fail to consistently disclose "Performance Indicators".
\end{abstract}

Keywords: corporate sustainability reporting, sustainability reports, GRI

\section{Introduction}

From the sustainability perspective corporations are being forced to redesign almost every part of their operations; from their strategies to objectives, to technologies, to product design, to production process, to business models etc. In other words, to maximize firm's value and create sustainable value in long term companies must achieve three elements of sustainable development, namely economical, social, and environmental sustainability.

Sustainability and reporting sustainability have been considered and discussed by governments, organizations, and academicians. The idea of sustainability is changing not only businesses' cultures, but it is also changing people's habits, life style, and plans as well. Sustainability is being defined as follows: "Sustainable development is development that meets the needs of current generations without compromising the ability of future generations to meet their own needs"(Sustainability Framework, 2011, p.19). "The global challenge is to ensure that organizations develop sustainably to reverse the previous erosion of natural resources, and to improve their environmental, social, and financial performance. This requires radical changes in the way they do business and the way we live our lives" (Sustainability Framework, 2011, p.5). Moradzadehfard and Moshashaei (2011, p.397) state the World Business Council of the Sustainable Development's (WBCSD) sustainability definition: "The sustainable development is a simultaneous activity for the economic prosperity, environmental quality and the social justice".

Sustainability reporting has become an active area of research and been dominated by large multinational corporations recently. The scope of reports, potential target audiences, and integration with financial reports have 
increased as well. However it has been stated that there is relatively little information available on the process of developing reports and how they are used. To be more reliable most of corporations have followed guidelines for corporate sustainability reporting. The well known set of voluntary guideline is the Global Reporting Initiative (GRI, 2006). The guideline basically focuses on context of corporate sustainability reports, corporations' sustainability vision, their performances, and objectives towards sustainability (Roca \& Searcy, 2012, p.103-105).

Sustainability accounting and related terms are discussed by academics in conferences and practices frequently. The relationship between accounting and sustainability is another topic that is also discussed (Schaltegger \& Burritt, 2010). Accountants affect sustainability and the quality of reporting sustainability. In fact, the International Federation of Accountants (IFAC) believes that accountants can play key roles on sustainability. IFAC published "Sustainability Framework 2.0 Professional Accountants as Integrators" and outlines statements that accountants can support their organizations to achieve sustainable development by; "defining and clarifying the terminology that an organization has decided to use (sustainability, corporate responsibility, or corporate social responsibility) and what it means in relation to the organization; establishing leadership, vision, values, and behaviors; ensuring appropriate governance structures are in place to strengthen implementation, monitoring, and accountability; effective stakeholder engagement; setting goals and targets; establishing the business case; integrating risk management and assessment; and engaging suppliers".

Many Turkish firms have been paying attention to sustainability reporting lately. Most of these firms disclose sustainability reports in their operations reports. "As a result of increasing importance of sustainable development and the need for the companies to address and manage environmental, social and governance issues in a competitive global market, the Istanbul Stock Exchange (ISE) and the Turkish Business Council for Sustainable Development (TBCSD) have planned to work on a project titled "ISE Sustainability Index" (SKD, 2012). Some firms are the members of Sustainability Disclosure Database and disclose their repots in the Database. Firms' sustainability reports are prepared and disclosed in various levels as G3, G2, G1, and A, B, and C level.

The GRI criteria or performance indicators have been used to evaluate firms' sustainability reports by researchers. In this study, selected nine Turkish firms' sustainability reports are being analyzed based on the GRI indicators.

\section{Sustainability Reporting: Studies and Practices}

Sustainability reporting has historically focused on private sector not on public sector (Williams et. al., 2011). Farneti and Guthrie (2009) agreed this statement and suggested that public sector also should be analyzed in perspective of sustainability and its reporting.

Sustainability reporting is mandatory in many countries. The laws and regulations outline how sustainability reporting must be. However, Joseph (2012) argued that with the emphasis on voluntarism, sustainability reporting is in a transition stage yet. In some countries sustainability reports reveal just some of its indicators properly. Murguia and Böhling (2013) stated that in some Argentinean firms environmental and economic indicators are the most contentious and least reported.

Number of firms who report sustainability has increased lately. "In the last decade, reporting of nonfinancial information has become widespread. According to the Global Reporting Initiative (GRI), only 44 firms followed GRI guidelines to report sustainability information in 2000 yet by 2010 , the number of organizations releasing sustainability reports, predominantly on a voluntary basis, grew to 1,973" (Ioannou \& Serafeim, 2012, p.2). Marimon et. al. (2012) indicate that even though many firms have participated in sustainability reporting, that is not enough when it is compared to the numbers of total firms worldwide.

Ioannou and Serafeim (2012) have analyzed the consequences of mandatory corporate sustainability reporting by using 58 countries' data. They report that after the adoption of mandatory sustainability reporting laws and regulations, the social responsibility of business leaders increases. They also conclude that mandatory corporate sustainability improve and develop sustainability development, employee training, and corporate governance.

Corporate sustainability reporting applications are increasing in some countries. Gurvitsh and Sidorova (2012) conducted a survey among 15 listed firms in Estonia and they concluded that corporate sustainability is not a "stranger in the night" for those firms however it is a "friend, one would like to spend more time with". Adams and Frost (2008) found that companies are adapting environmental and social indicators of sustainability while they take these indicators into account in strategic planning process, performance measurements, decision making, and risk management. Chang et. al. (2011) analyzed corporate sustainability performance of 16 
industries by Data Envelopment Analysis (DEA) and found that 7 of those industries improved their sustainability performances.

Rowbottom and Lymer (2009) examined the website users of sustainability reports and their requires. They found that vast majority of requests come from employees, private individuals, and consultants. They also indicated that professional investors, creditors, and accounting firms mostly focused on the annual reports, significantly less focused on the sustainability reports.

Searcy and Elkhawas (2012) analyzed 24 listed firms in terms of using Dow Jones Sustainability Index (DJSI) in some aspects such as using its logo. They state that less than half of those firms use the logo of DJSI in their sustainability reports and websites for increasing ability of stakeholders to understand sustainability reports which would help them making different decisions than from their competitors.

Albu et. al. (2011, p.223) state that literature indicates four benefits of Corporate Social Responsibility (CSR): CSR reduces direct costs (energy, materials, time loss, etc.); improves productivity of workers (increased motivation, low absenteeism, reduced turnover); reduces management risk (easier access to credit, increased value of the assets for investors, support by stakeholders, etc.); and improves the competitive image of the firm.

Some researchers investigated the relationship between corporate social responsibility and firm's attributes and specifics. The results show a positive association between proportion of Independent Directors (INDs) and Corporate Social Responsibility Disclosure (CSRD). Some other results indicate that firm's size has no effect on CSR but Board Leadership Structure, Board Audit Committee, Return on Equity are positively related to CSR (Rouf, 2011).

There are few studies related to sustainability reporting in Turkey. Başar and Başar (2006) analyzed 100 largest listed Turkish firms' sustainability profile. According to the researchers most of the firms' sustainability reports are disclosed in their operations reports, but not separately. The firms' sustainability reports mostly reveal information related to human resources, health and safety issues. In addition to that the study reveals that the listed firms' reports do not disclose enough details about sustainability profile of the firms. Senal and Aslantaş Ateş (2012) state that sustainability development promotes using various accounting and costing methods such as environmental accounting, environmental managerial accounting, and life cycle costing.

Based on the answers to the survey related sustainability, it can be seen that most firms have difficulties in understanding and applying sustainability concepts. Especially environmental issues are not being priorities of many firms. However many firms have interested mostly in social and economic elements of sustainability (Sustainability Survey, 2011, p.9).

\section{Corporate Sustainability Reporting and Dimensions of Sustainability}

"Sustainability", "environmental, social and governance" (ESG), "non-financial" or "corporate social responsibility" (CSR) reporting have been used interchangeably in the past, to present environmental, social or governance issues in the related reports (Ioannou \& Serafeim, 2012, p.2).

Although "Sustainability" and "Corporate Social Responsibility" (CSR) terms have often been used inter-changeably, they indicate different points. "Sustainability is more of an over-arching concept which seeks to promote continuous long term growth in all the various forms of capital available to us - financial, natural and social. By contrast many see CSR as a more limited concept, focused on shorter-term issues and activities such as legal compliance, philanthropy and improvement in workforce conditions. In general it might be said all organizations aspire to being responsible but few would claim to be truly sustainable" (IFAC, 2006, p.1).

In the published literature there is no commonly accepted definition of corporate reporting or a corporate report. Roca and Searcy (2012, p.104) state that some researchers define a sustainability report as "a report which must contain qualitative and quantitative information on the extent to which the company has managed to improve its economic, environmental and social effectiveness and efficiency in the reporting period and integrate these aspects in a sustainability management system". Roca and Searcy $(2012$, p.105) also indicate that the World Business Council for Sustainable Development's definition is similar; WBCSD (2002) defines "sustainable development reports as public reports by companies to provide internal and external stakeholders with a picture of the corporate position and activities on economic, environmental and social dimensions".

There are three dimensions of sustainability; economic viability, social responsibility, and environmental responsibility. "While trade-offs can occur between these dimensions, they are interconnected in various ways. For example, being socially and environmentally responsible (toward employees, communities, and other stakeholders), leads to enhanced trust, and, therefore, makes good business sense. Social and environmental responsibility cannot stand in isolation from economic viability. Organizations must continue to provide 
products and services that people want in order to generate profits, growth, and new jobs. While pursuing a commercial imperative, organizations must also take into account their social and environmental impact as part of ensuring that they generate added value for an organization and its stakeholders" (Sustainability Framework, 2011, p.8).

\section{Corporate Sustainability Reporting and Stakeholder Engagement}

Stakeholder engagement is vital to firms in creating value and viable operations. Stakeholder engagement is basically informing different stakeholder groups and considering their opinions in decision making process of a firm. Successful firms are certainly keen to identify the means of engaging stakeholders in that process. Somehow failing in stakeholder engagement would lead to several negative results: poor performance, unsatisfied customers, frustrated employees, damaging supply chain, possible compromising a firm's reputation with the wider community. In fact the quality of sustainability reporting clearly depends on successful stakeholder engagement. Reflecting stakeholder's opinion in decision making process possibly could help better dealing with anticipated issues and be more proactive compared to the firms that are not involved in this process (Sustainable Framework, 2011, p.34-35).

Global Reporting Initiative (GRI) reporting principles that are stated in "G3 Sustainability Reporting Guidelines" outline how stakeholders are included to the process of business: "The reporting organization should identify its stakeholders and explain in the report how it has responded to their reasonable expectations and interests" (Sustainable Framework, 2011, p.35). By doing that firms craft and implement their strategy, attain social, environmental, and economical elements of sustainability goals. Therefore, stakeholder engagement helps to build skills of being proactive instead of being reactive.

The 2008 KPMG International Survey of Corporate Responsibility Reporting presents how stakeholder engagement is being considered by large companies in 22 countries (Global Fortune 250 (G250), 100 largest companies by revenue (N100)). According to the survey more than $50 \%$ of the companies somehow structured stakeholder engagement by formal or informal techniques. $60 \%$ of G250 companies disclose of information about their stakeholders and how the engagement is being done. Most of these companies indicate that stakeholder engagement help them to search a way of reducing risk and exploiting new creative business opportunities with corporate responsibility (Sustainable Framework, 2011, p.36).

\section{Global Reporting Initiative (GRI)}

GRI is the most well known guideline for sustainability reporting. The objective of GRI is to mainstream "disclosure on environmental, social and governance performance". The GRI G3 was released in 2006 and updated in 2011 as Version 3.1 (Roca \& Searcy, 2012, p.105). Figure 1 presents how GRI guideline outlines the reporting process. Inputs are the principles and guidance, outputs are standard disclosure. 


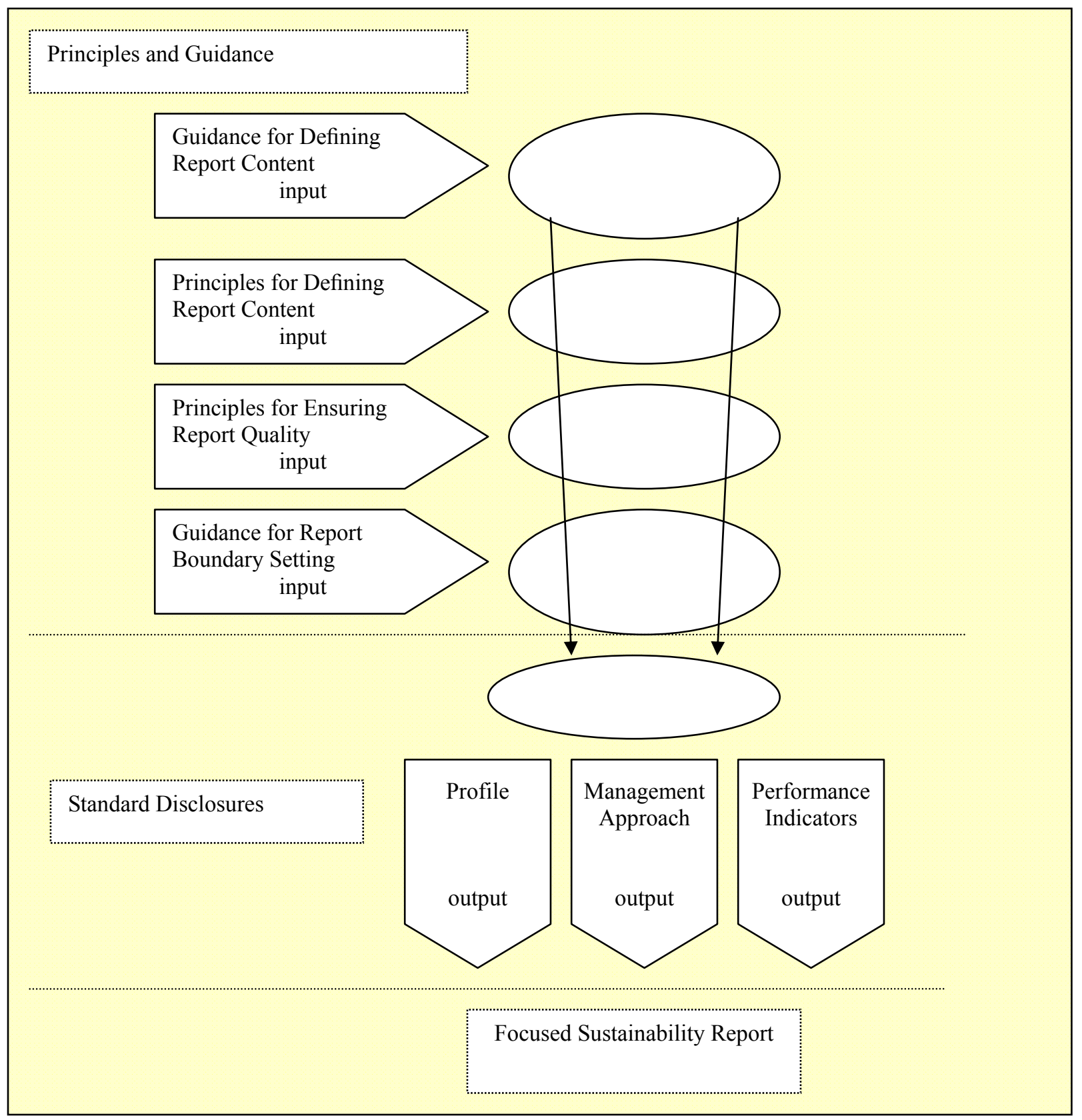

Figure 1. Overview of the GRI guidelines

Source: Sustainability Reporting Guideline, 2006, Version 3, p.4.

The GRI criteria or performance indicators have been used to analyze firms' sustainability reports by researchers. Roca and Searcy (2012) analyzed 94 corporations' sustainability reports to identify the indicators disclosed in the reports and also investigated the use of indicators of GRI. Their findings suggested that 31 of the 94 reports included indicators explicitly identified as GRI indicators. The researchers stated that "the most reported GRI indicators appeared in 28 of the reports, while the least reported indicators appeared in 5 of the reports".

\section{Analyzing Sustainability Reports in Turkey}

\subsection{Data and Methodology}

In this study selected sustainability reports of 9 non-financial companies are analyzed. Numbers of the reports based on application levels are: 1 level A report, 1 level B+ report, 5 level B reports, and 2 level C reports. The application level of reports can be plus (+) if external assurance was utilized for the report. As detailed in Table 1, 
application level C is not required to disclose Part II indicators. Level B is required to report fully on a minimum of any 20 "Performance Indicators", at least one from each of: economic, environment, human rights, labor, society, and product responsibility (GRI Application Levels, 2010-2011, Version 3.1).

The content analysis method is used based on the indicators of GRI. 3 firms' sustainability reports (Arçelik, Aygaz, and Efes reports) analyses are done manually as abstracting from the content table of the reports. However, 6 sustainability reports' content analysis data (Bilim, Akçansa, Koç Holding, Coca-Cola, Opet, and Zorlu Energy) is obtained from Sustainability Disclosure Database. All the selected sustainability reports were prepared based on 2006 Guideline, G3 type.

Sustainability reports used in this study were scored based on indicators that guided by GRI. Fully reported indicator is scored as (2), partially reported is scored as (1), and finally not reported indicator is scored as zero (0). If a firm's sustainability report meets all the principles and standards of GRI Guideline, the firm could reach to the maximum score of (310).

Table 1. Minimum application level criteria and maximum score

\begin{tabular}{|c|c|c|c|c|c|c|}
\hline \multirow{4}{*}{ Application Level } & \multirow{4}{*}{$\mathrm{C}$} & \multirow{4}{*}{ B } & \multirow{4}{*}{ A } & \multirow[t]{4}{*}{$\begin{array}{l}\text { Total Number of } \\
\text { Indicators } \\
\text { (Max.) }\end{array}$} & \multicolumn{2}{|c|}{$\begin{array}{c}\text { Max. Score } \\
\text { (indicators*score) } \\
\text { Score: }\end{array}$} \\
\hline & & & & & Reported & $: 2$ \\
\hline & & & & & Partially Reported & \\
\hline & & & & & Not Reported & $: 0$ \\
\hline Part I number of indicators & 24 & 42 & 42 & 42 & 84 & \\
\hline Part II number of indicators & Not required & $\begin{array}{l}\text { each indicator or } \\
\text { category }\end{array}$ & $\begin{array}{c}\text { each indicator } \\
\text { or category }\end{array}$ & 34 & 68 & \\
\hline $\begin{array}{l}\text { Part III number of } \\
\text { indicators }\end{array}$ & Minimum 10 & Minimum 20 & $55+$ & 79 & 158 & \\
\hline
\end{tabular}

Source: Generated from GRI Application Level, 3.1, 2010-2011 and (http://3blmedia.com/media/3bl.png).

Based on GRI to meet minimum requirements, Level C firm must disclose 24 indicators of Part I, minimum 10 indicators of Part III and none of Part II. Level B firm must disclose all indicators of Part I and Part II, and minimum 20 indicators of Part III. Level A firm must disclose all indicators of Part I and Part II, and minimum 55 indicators of Part III. As provided in Table 1, if a firm discloses all 42 indicators of Part I, its score is maximum 84; all 34 indicators of Part II, its score is maximum 68; and all 79 indicators of Part III, its score is maximum 158. Hence the highest score a firm could reach is 310 as shown in Appendix.

\subsection{Results}

Results based on GRI indicators are summarized in Table 2. The Table actually is abstracted from Appendix. The Table provides three parts of sustainability reports that are widely accepted and used by GRI Guide. First part presents firms' "Profile Disclosure" level that contains "Profile, Reporting Parameters, and Governance, Commitments, and Engagement" elements. The second part presents "Disclosure on Management Approach (DMA)". The third part is related to "performance indicators" that are outlined as "Economic, Environmental, Labor Practices and Decent Work, Human Rights, Society, and Product Responsibility". 
Table 2. Summary of firms' content analysis

\begin{tabular}{|c|c|c|c|c|c|c|c|c|c|c|}
\hline $\begin{array}{l}\text { GRI Indicators / Firms/ } \\
\text { Publication Year: } \\
\text { 2011-2012 }\end{array}$ & $\begin{array}{l}\text { Bilim } \\
\text { P.Comp } \\
2010\end{array}$ & $\begin{array}{c}\text { Akçansa } \\
\text { 2007-2009 } \\
\end{array}$ & $\begin{array}{c}\text { Koç } \\
\text { Holding } \\
2010\end{array}$ & $\begin{array}{c}\text { Coca-Cola } \\
2011\end{array}$ & $\begin{array}{c}\text { Arçelik } \\
2010\end{array}$ & $\begin{array}{c}\text { Aygaz } \\
2010-2011 \\
\end{array}$ & $\begin{array}{c}\text { Efes } \\
2009-2010\end{array}$ & $\begin{array}{l}\text { Opet } \\
2010\end{array}$ & $\begin{array}{l}\text { Zorlu } \\
\text { Energy } \\
2010\end{array}$ & $\begin{array}{l}\text { Max. } \\
\text { score }\end{array}$ \\
\hline $\begin{array}{l}\text { Type of Report/Application } \\
\text { level }\end{array}$ & G3-A & G3-B & G3-B & G3-B & G3-B+ & G3-B & G3-B & G3-C & G3-C & \\
\hline Part I: Profile Disclosures & 84 & 84 & 84 & 84 & 84 & 84 & 84 & 58 & 84 & 84 \\
\hline 1-2. Profile & 24 & 24 & 24 & 24 & 24 & 24 & 24 & 22 & 24 & 24 \\
\hline 3. Reporting Parameters & 26 & 26 & 26 & 26 & 26 & 26 & 26 & 24 & 26 & 26 \\
\hline Report Profile & 8 & 8 & 8 & 8 & 8 & 8 & 8 & 8 & 8 & 8 \\
\hline Report Scope and Boundary & 14 & 14 & 14 & 14 & 14 & 14 & 14 & 12 & 14 & 14 \\
\hline GRI Content Index & 2 & 2 & 2 & 2 & 2 & 2 & 2 & 2 & 2 & 2 \\
\hline Assurance & 2 & 2 & 2 & 2 & 2 & 2 & 2 & 2 & 2 & 2 \\
\hline $\begin{array}{l}\text { 4. Governance, } \\
\text { Commitments, and } \\
\text { Engagement }\end{array}$ & 34 & 34 & 34 & 34 & 34 & 34 & 34 & 12 & 34 & 34 \\
\hline Governance & 20 & 20 & 20 & 20 & 20 & 20 & 20 & 8 & 20 & 20 \\
\hline $\begin{array}{l}\text { Commitment to External } \\
\text { Initiatives }\end{array}$ & 6 & 6 & 6 & 6 & 6 & 6 & 6 & 0 & 6 & 6 \\
\hline $\begin{array}{l}\text { Stakeholder Engagement } \\
\text { Part II: Disclosures on }\end{array}$ & 8 & 8 & 8 & 8 & 8 & 8 & 8 & 4 & 8 & 8 \\
\hline $\begin{array}{l}\text { Management Approach } \\
\text { (DMA) }\end{array}$ & 68 & 64 & 68 & 68 & 68 & $\mathbf{0}$ & 68 & $\mathbf{0}$ & 68 & 68 \\
\hline $\begin{array}{l}\text { Part III: Performance } \\
\text { Indicators }\end{array}$ & 122 & 104 & 64 & 93 & 119 & 115 & 114 & 56 & 146 & 158 \\
\hline Economic & 14 & 12 & 8 & 14 & 13 & 15 & 17 & 9 & 18 & 18 \\
\hline Environmental & 49 & 28 & 21 & 25 & 55 & 33 & 43 & 9 & 48 & 60 \\
\hline $\begin{array}{l}\text { Labor Practices and Decent } \\
\text { Work }\end{array}$ & 22 & 24 & 17 & 21 & 26 & 25 & 19 & 15 & 28 & 28 \\
\hline Human Rights & 10 & 14 & 9 & 8 & 14 & 13 & 12 & 7 & 18 & 18 \\
\hline Society & 10 & 10 & 6 & 7 & 5 & 13 & 10 & 7 & 16 & 16 \\
\hline Product Responsibility & 17 & 16 & 3 & 18 & 6 & 16 & 13 & 9 & 18 & 18 \\
\hline TOTAL & 274 & 252 & 216 & 245 & 271 & 199 & 266 & 114 & 298 & 310 \\
\hline
\end{tabular}

Several results can be generated from Table 2. The first one is about Part I. As presented in Table 2, selected firms sustainability reports Part I indicators are fully reported except in one firm's report (Opet). Since the firms' application level is $\mathrm{C}$, those indicators are not disclosed. Those indicators could be reported voluntarily as other C level firm did (Zorlu Energy). Selected firms' sustainability reports clearly have disclosed "Profile Disclosures". It can be said that firms fulfill requirements related to Part I based on their reports application level.

The second results are related to Part II, "Disclosures on Management Approach". Almost seven selected reports disclosed those indicators fully in their reports while two firms disclosed none of the indicators. This situation can be explained by reports' application levels. C level reports are not required to disclose those indicators unless they voluntarily do it. Although level B reports are required to disclose Part II indicators, one B application level firm (Aygaz) did not reported such indicators in its content table. As one of the elements of Part II, firms' stakeholder engagement scores are consistent among reports.

The third results state disclosure level of "Performance Indicators", Part III. Most interesting result of the study is in the third part. Based on the disclosing level, firms' reports meet minimum requirements. However, disclosing Part III indicators varies significantly among the same application level firms. For example Koç Holding's score is 64 while Arçelik's score is 119 for the total of Part III indicators. There is inconsistency between $\mathrm{C}$ level reports as well. One report has much higher score than the other. It can be concluded that firms' sustainability reports fail to consistently disclose Performance Indicators.

In Part III category, only one firm's report (Zorlu Energy) meets the maximum scores except one subcategory, environmental indicators. Most of the firms' environmental disclosure level is not close to the maximum score. There is no consistency disclosing other performance indicators between firms' reports as well. Except one 
firm's report, all the reports do not fully report "Economic, Labor Practices and Decent Work, Human Rights, Society, and Product Responsibility" indicators.

\section{Conclusions}

Reporting sustainability is a key process to inform stakeholders whether the firm is achieving sustainable growth and value for their interest. To be more reliable most corporations have followed guidelines for corporate sustainability reporting. The well known set of voluntary guideline is the Global Reporting Initiative (GRI, 2006). The guideline basically focuses on the context of corporate sustainability reports, corporations' sustainability vision, their performances, and objectives towards sustainability.

The GRI criteria or performance indicators have been used to analyze firms' sustainability reports by researchers. In this study selected nine Turkish firms' sustainability reports have been analyzed based on the GRI indicators. The results show that selected firms' sustainability reports usually meet the minimum requirements of the GRI standards based on their application level. However there are differences between firms' scores even though they are in the same application level. Some firms reveal more information than others, but in general firms do not disclose many indicators voluntarily.

It can be said that firms fulfill requirements related to Part I and Part II, "Profile Disclosures" and "Disclosures on Management Approach" based on their reports' application level. However, it is hard to say the same thing for the Part III. In fact firms' sustainability reports fail to consistently disclose "Performance Indicators".

The effort of preparing sustainability index in Istanbul Stock Exchange is the evidence that Turkey and Turkish firms are paying more attention to reporting sustainability. However, most firms are still behind of this trend. Regular reporting of sustainability and the disclosure level has several problems needed to be solved. Mandatory regulations may provide better sustainability reporting environment. There are many possibilities for future research in this field. For example, studies could explore relations between firms' performance and level of disclosure.

\section{References}

Adams, C. A., \& Frost, G. R. (2008). Integrating Sustainability Reporting into Management Practices. Accounting Forum, 32, 288-302. http://dx.doi.org/10.1016/j.accfor.2008.05.002

Albu, N., Albu, C. N., Gîrbină, M. M., \& Sandu, M. I. (2011). The Implications of Corporate Social Responsibility on the Accounting Profession: The Case of Romania. Corporate Social Responsibility, XIII(29), 221-234.

Başar, A. B., \& Başar, M. (2006). Social Responsibility Reporting: The Case of Turkey. Sosyal Bilimler Dergisi, 2, 213-230.

Chang, D. S., Kuo, L. R., \& Chen, Y. (2011). Industrial Changes in Corporate Sustainability Performance - An Empirical Overview Using Data Envelopment Analysis. Journal of Cleaner Production, xxx, 1-9.

Farneti, F., \& Guthrie, J. (2009). Sustainability Reporting by Australian Public Sector Organisations: Why They Report. Accounting Forum, 33, 89-98. http://dx.doi.org/10.1016/j.accfor.2009.04.002

GRI Application Levels. (2010-2011). 3.1.

Gurvitsh, N., \& Sidorova, I. (2012). Survey of Sustainability Reporting Integrated into Annual Reports of Estonian Companies for the Years 2007-2010: Based on Companies Listed on Tallinn Stock Exchange as of October 2011. Procedia Economics and Finance, 2, 26-34. http://dx.doi.org/10.1016/S2212-5671(12)00061-5

IFAC, Information Paper. (2006). Why Sustainability Counts for Professional Accountants in Business. Professional Accountants in Business Committee, 1-8.

Ioannou, I., \& Serafeim, G. (2012). The Consequences of Mandatory Corporate Sustainability Reporting. Working Paper, Harvard Business School.

Joseph, G. (2012). Ambiguous but Tethered: An Accounting Basis for Sustainability Reporting. Critical Perspectives on Accounting, 23, 93-106. http://dx.doi.org/10.1016/j.cpa.2011.11.011

Marimon, F., Alonso-Almeida, M. M., Rodrigez, M. P., \& Alejandro, K. A. C. (2012). The Worldwide Diffusion of the Global Reporting Initiative: What is The Point?. Journal of Cleaner Production, 33, 132-144. http://dx.doi.org/10.1016/j.jclepro.2012.04.017 
Moradzadehfard, M., \& Moshashaei, M. (2011). The Accountants' Role in Organizations' Sustainability (Regarding Sustainability Framework of the International Federation of Accountants (IFAC)). European Journal of Scientific Research, 59(3), 396-402.

Murguia, D. I., \& Böhling, K. (2013). Sustainability Reporting on Large-Scale Mining Conflicts: The Case of Bajo De La Alumbrera, Argentina. Journal of Cleaner Production, 41, 202-209. http://dx.doi.org/10.1016/j.jclepro.2012.10.012

Roca, L. C., \& Searcy, C. (2012). An Analysis of Indicators Disclosed in Corporate Sustainability Reports. Journal of Cleaner Production, 20, 103-118. http://dx.doi.org/10.1016/j.jclepro.2011.08.002

Rouf, A. (2011). The Corporate Social Responsibility Disclosure: A Study of Listed Companies in Bangladesh. Business and Economics Research Journal, 2(3), 19-32.

Rowbottom, N., \& Lymer, A. (2009). Exploring the Use of Online Corporate Sustainability Information. Accounting Forum, 33, 176-186. http://dx.doi.org/10.1016/j.accfor.2009.01.003

Schaltegger, S., \& Burritt, R. L. (2010). Sustainability Accounting for Companies: Catchphrase or Decision Support for Business Leaders?. Journal of World Business, 45, 375-384. http://dx.doi.org/10.1016/j.jwb.2009.08.002

Searcy, C., \& Elkhawas, D. (2012). Corporate Sustainability Ratings: An Investigation into How Corporations Use The Dow Jones Sustainability Index. Journal of Cleaner Production, 35, 79-92. http://dx.doi.org/10.1016/j.jclepro.2012.05.022

Senal, S., \& Aslantaş Ateş, B. (2012). Kurumsal Sürdürülebilirlik için Muhasebe ve Raporlama. Muhasebe ve Denetime Bakış. Nisan, 83-977.

SKD. (2012). http://www.tbcsd.org/?Lisan=EN, (August 2012).

Sustainability Disclosure Database. (August 2012). http://database.globalreporting.org/

Sustainability Framework 2.0. (2011). Professional Accountants as Integrators, p. 1-202.

Sustainability Reporting Guidelines (RG). (2000-2006). GRI, Version 3.0, Global Reporting Initiative, p. 1-44.

Sustainability Survey. (2011). Türk İş Dünyası'nda Sürdürülebilirlik Uygulamaları Değerlendirme Raporu. Eylül 2011, 1-50,

Williams, B., Wilmshurst, T., \& Clift, R. (2011). Sustainability Reporting by Local Government in Australia: Current and Future Prospects. Accounting Forum, 35, 176-186. http://dx.doi.org/10.1016/j.accfor.2011.06.004

\begin{tabular}{|c|c|c|c|c|c|c|c|c|c|c|}
\hline $\begin{array}{l}\text { GRI Indicators / Firms/ } \\
\text { publication year 2011-12 }\end{array}$ & $\begin{array}{c}\text { Bilim } \\
\text { P.Comp. }\end{array}$ & Akçansa & $\begin{array}{c}\text { Koç } \\
\text { Holding } \\
\text { A.Ş. }\end{array}$ & $\begin{array}{l}\text { Coca-Cola } \\
\text { İçecek }\end{array}$ & Arçelik & Aygaz & Efes & $\begin{array}{l}\text { OPET } \\
\text { Petrol. }\end{array}$ & $\begin{array}{l}\text { Zorlu } \\
\text { Energy }\end{array}$ & $\begin{array}{l}\max \\
\text { score }\end{array}$ \\
\hline Year & 2010 & 2007-2009 & 2010 & 2011 & 2010 & 2010-11 & 2009-10 & 2010 & 2010 & \\
\hline $\begin{array}{l}\text { Type of } \\
\text { Report/Application level } \\
\text { Part I: Profile Disclosures }\end{array}$ & G3-A & G3-B & G3-B & G3-B & G3-B+ & G3-B & G3-B & G3-C & G3-C & \\
\hline Score of profile & 24 & 24 & 24 & 24 & 24 & 24 & 24 & 22 & 24 & 24 \\
\hline 1.1. & 2 & 2 & 2 & 2 & 2 & 2 & 2 & 2 & 2 & 2 \\
\hline 1.2. & 2 & 2 & 2 & 2 & 2 & 2 & 2 & 0 & 2 & 2 \\
\hline 2.1. & 2 & 2 & 2 & 2 & 2 & 2 & 2 & 2 & 2 & 2 \\
\hline 2.2. & 2 & 2 & 2 & 2 & 2 & 2 & 2 & 2 & 2 & 2 \\
\hline 2.3. & 2 & 2 & 2 & 2 & 2 & 2 & 2 & 2 & 2 & 2 \\
\hline 2.4 & 2 & 2 & 2 & 2 & 2 & 2 & 2 & 2 & 2 & 2 \\
\hline 2.5 & 2 & 2 & 2 & 2 & 2 & 2 & 2 & 2 & 2 & 2 \\
\hline 2.6. & 2 & 2 & 2 & 2 & 2 & 2 & 2 & 2 & 2 & 2 \\
\hline 2.7 & 2 & 2 & 2 & 2 & 2 & 2 & 2 & 2 & 2 & 2 \\
\hline 2.8. & 2 & 2 & 2 & 2 & 2 & 2 & 2 & 2 & 2 & 2 \\
\hline 2.9 & 2 & 2 & 2 & 2 & 2 & 2 & 2 & 2 & 2 & 2 \\
\hline 2.10 & 2 & 2 & 2 & 2 & 2 & 2 & 2 & 2 & 2 & 2 \\
\hline
\end{tabular}




\begin{tabular}{|c|c|c|c|c|c|c|c|c|c|c|}
\hline 3. Reporting Parameters & 26 & 26 & 26 & 26 & 26 & 26 & 26 & 24 & 26 & 26 \\
\hline Report Profile & 8 & 8 & 8 & 8 & 8 & 8 & 8 & 8 & 8 & 8 \\
\hline 3.1 & 2 & 2 & 2 & 2 & 2 & 2 & 2 & 2 & 2 & 2 \\
\hline 3.2 . & 2 & 2 & 2 & 2 & 2 & 2 & 2 & 2 & 2 & 2 \\
\hline 3.3 . & 2 & 2 & 2 & 2 & 2 & 2 & 2 & 2 & 2 & 2 \\
\hline 3.4 . & 2 & 2 & 2 & 2 & 2 & 2 & 2 & 2 & 2 & 2 \\
\hline $\begin{array}{l}\text { Report Scope and } \\
\text { Boundary }\end{array}$ & 14 & 14 & 14 & 14 & 14 & 14 & 14 & 12 & 14 & 14 \\
\hline 3.5. & 2 & 2 & 2 & 2 & 2 & 2 & 2 & 2 & 2 & 2 \\
\hline 3.6 . & 2 & 2 & 2 & 2 & 2 & 2 & 2 & 2 & 2 & 2 \\
\hline 3.7 . & 2 & 2 & 2 & 2 & 2 & 2 & 2 & 2 & 2 & 2 \\
\hline 3.8 . & 2 & 2 & 2 & 2 & 2 & 2 & 2 & 2 & 2 & 2 \\
\hline 3.9. & 2 & 2 & 2 & 2 & 2 & 2 & 2 & 0 & 2 & 2 \\
\hline 3.10 & 2 & 2 & 2 & 2 & 2 & 2 & 2 & 2 & 2 & 2 \\
\hline 3.11 & 2 & 2 & 2 & 2 & 2 & 2 & 2 & 2 & 2 & 2 \\
\hline GRI Content Index & 2 & 2 & 2 & 2 & 2 & 2 & 2 & 2 & 2 & 2 \\
\hline 3.12 & 2 & 2 & 2 & 2 & 2 & 2 & 2 & 2 & 2 & 2 \\
\hline Assurance & 2 & 2 & 2 & 2 & 2 & 2 & 2 & 2 & 2 & 2 \\
\hline 3.13 & 2 & 2 & 2 & 2 & 2 & 2 & 2 & 2 & 2 & 2 \\
\hline \multicolumn{11}{|l|}{ 4. Governance, } \\
\hline Commitments, and & 34 & 34 & 34 & 34 & 34 & 34 & 34 & 12 & 34 & 34 \\
\hline \multicolumn{11}{|l|}{ Engagement } \\
\hline Governance & 20 & 20 & 20 & 20 & 20 & 20 & 20 & 8 & 20 & 20 \\
\hline 4.1 & 2 & 2 & 2 & 2 & 2 & 2 & 2 & 2 & 2 & 2 \\
\hline 4.2 . & 2 & 2 & 2 & 2 & 2 & 2 & 2 & 2 & 2 & 2 \\
\hline 4.3 . & 2 & 2 & 2 & 2 & 2 & 2 & 2 & 2 & 2 & 2 \\
\hline 4.4 . & 2 & 2 & 2 & 2 & 2 & 2 & 2 & 2 & 2 & 2 \\
\hline 4.5 . & 2 & 2 & 2 & 2 & 2 & 2 & 2 & 0 & 2 & 2 \\
\hline 4.6 . & 2 & 2 & 2 & 2 & 2 & 2 & 2 & 0 & 2 & 2 \\
\hline 4.7. & 2 & 2 & 2 & 2 & 2 & 2 & 2 & 0 & 2 & 2 \\
\hline 4.8. & 2 & 2 & 2 & 2 & 2 & 2 & 2 & 0 & 2 & 2 \\
\hline 4.9 . & 2 & 2 & 2 & 2 & 2 & 2 & 2 & 0 & 2 & 2 \\
\hline 4.10 & 2 & 2 & 2 & 2 & 2 & 2 & 2 & 0 & 2 & 2 \\
\hline $\begin{array}{l}\text { Commitment to External } \\
\text { Initiatives }\end{array}$ & 6 & 6 & 6 & 6 & 6 & 6 & 6 & $\mathbf{0}$ & 6 & 6 \\
\hline 4.11 & 2 & 2 & 2 & 2 & 2 & 2 & 2 & 0 & 2 & 2 \\
\hline 4.12. & 2 & 2 & 2 & 2 & 2 & 2 & 2 & 0 & 2 & 2 \\
\hline 4.13. & 2 & 2 & 2 & 2 & 2 & 2 & 2 & 0 & 2 & 2 \\
\hline Stakeholder Engagement & 8 & 8 & 8 & 8 & 8 & 8 & 8 & 4 & 8 & 8 \\
\hline 4.14 & 2 & 2 & 2 & 2 & 2 & 2 & 2 & 2 & 2 & 2 \\
\hline 4.15. & 2 & 2 & 2 & 2 & 2 & 2 & 2 & 2 & 2 & 2 \\
\hline 4.16. & 2 & 2 & 2 & 2 & 2 & 2 & 2 & 0 & 2 & 2 \\
\hline 4.17 & 2 & 2 & 2 & 2 & 2 & 2 & 2 & 0 & 2 & 2 \\
\hline Part I - Total & 84 & 84 & 84 & 84 & 84 & 84 & 84 & 58 & 84 & 84 \\
\hline \multicolumn{11}{|l|}{ Part II: Disclosures on } \\
\hline \multicolumn{11}{|l|}{ Management Approach } \\
\hline \multicolumn{11}{|l|}{$($ DMA $)$} \\
\hline \multicolumn{11}{|l|}{-DMA EC } \\
\hline -Economic performance & 2 & 2 & 2 & 2 & 2 & 0 & 2 & 0 & 2 & 2 \\
\hline -Market presence & 2 & 2 & 2 & 2 & 2 & 0 & 2 & 0 & 2 & 2 \\
\hline -Indirect economic impacts & 2 & 2 & 2 & 2 & 2 & 0 & 2 & 0 & 2 & 2 \\
\hline \multicolumn{11}{|l|}{-DMA EN } \\
\hline -Materials & 2 & 2 & 2 & 2 & 2 & 0 & 2 & 0 & 2 & 2 \\
\hline -Energy & 2 & 2 & 2 & 2 & 2 & 0 & 2 & 0 & 2 & 2 \\
\hline -Water & 2 & 1 & 2 & 2 & 2 & 0 & 2 & 0 & 2 & 2 \\
\hline -Biodiversity & 2 & 2 & 2 & 2 & 2 & 0 & 2 & 0 & 2 & 2 \\
\hline
\end{tabular}




\begin{tabular}{|c|c|c|c|c|c|c|c|c|c|c|}
\hline $\begin{array}{l}\text {-Emissions, effluents and } \\
\text { waste }\end{array}$ & 2 & 2 & 2 & 2 & 2 & 0 & 2 & 0 & 2 & 2 \\
\hline -Products and services & 2 & 1 & 2 & 2 & 2 & 0 & 2 & 0 & 2 & 2 \\
\hline -Compliance-EN & 2 & 2 & 2 & 2 & 2 & 0 & 2 & 0 & 2 & 2 \\
\hline -Transport & 2 & 0 & 2 & 2 & 2 & 0 & 2 & 0 & 2 & 2 \\
\hline -Overall & 2 & 2 & 2 & 2 & 2 & 0 & 2 & 0 & 2 & 2 \\
\hline \multicolumn{11}{|l|}{-DMA LA } \\
\hline -Employment & 2 & 2 & 2 & 2 & 2 & 0 & 2 & 0 & 2 & 2 \\
\hline $\begin{array}{l}\text {-Labor/management } \\
\text { relations }\end{array}$ & 2 & 2 & 2 & 2 & 2 & 0 & 2 & 0 & 2 & 2 \\
\hline $\begin{array}{l}\text {-Occupational health and } \\
\text { safety }\end{array}$ & 2 & 2 & 2 & 2 & 2 & 0 & 2 & 0 & 2 & 2 \\
\hline -Training and education & 2 & 2 & 2 & 2 & 2 & 0 & 2 & 0 & 2 & 2 \\
\hline $\begin{array}{l}\text {-Diversity and equal } \\
\text { opportunity }\end{array}$ & 2 & 2 & 2 & 2 & 2 & 0 & 2 & 0 & 2 & 2 \\
\hline \multicolumn{11}{|l|}{-DMA HR } \\
\hline $\begin{array}{l}\text {-Investment and } \\
\text { procurement practices }\end{array}$ & 2 & 2 & 2 & 2 & 2 & 0 & 2 & 0 & 2 & 2 \\
\hline -Non-discrimination & 2 & 2 & 2 & 2 & 2 & 0 & 2 & 0 & 2 & 2 \\
\hline $\begin{array}{l}\text {-Freedom of association and } \\
\text { collective bargaining }\end{array}$ & 2 & 2 & 2 & 2 & 2 & 0 & 2 & 0 & 2 & 2 \\
\hline -Child labor & 2 & 2 & 2 & 2 & 2 & 0 & 2 & 0 & 2 & 2 \\
\hline $\begin{array}{l}\text {-Forced and compulsory } \\
\text { labor }\end{array}$ & 2 & 2 & 2 & 2 & 2 & 0 & 2 & 0 & 2 & 2 \\
\hline -Security practices & 2 & 2 & 2 & 2 & 2 & 0 & 2 & 0 & 2 & 2 \\
\hline -Indigenous rights & 2 & 2 & 2 & 2 & 2 & 0 & 2 & 0 & 2 & 2 \\
\hline \multicolumn{11}{|l|}{-DMA SO } \\
\hline -Community & 2 & 2 & 2 & 2 & 2 & 0 & 2 & 0 & 2 & 2 \\
\hline -Corruption & 2 & 2 & 2 & 2 & 2 & 0 & 2 & 0 & 2 & 2 \\
\hline -Public policy & 2 & 2 & 2 & 2 & 2 & 0 & 2 & 0 & 2 & 2 \\
\hline -Anti-competitive behavior & 2 & 2 & 2 & 2 & 2 & 0 & 2 & 0 & 2 & 2 \\
\hline -Compliance-SO & 2 & 2 & 2 & 2 & 2 & 0 & 2 & 0 & 2 & 2 \\
\hline \multicolumn{11}{|l|}{-DMA PR } \\
\hline -Customer health and safety & 2 & 2 & 2 & 2 & 2 & 0 & 2 & 0 & 2 & 2 \\
\hline $\begin{array}{l}\text {-Product and service } \\
\text { labelling }\end{array}$ & 2 & 2 & 2 & 2 & 2 & 0 & 2 & 0 & 2 & 2 \\
\hline -Marketing communications & 2 & 2 & 2 & 2 & 2 & 0 & 2 & 0 & 2 & 2 \\
\hline -Customer privacy & 2 & 2 & 2 & 2 & 2 & 0 & 2 & 0 & 2 & 2 \\
\hline -Compliance-PR & 2 & 2 & 2 & 2 & 2 & 0 & 2 & 0 & 2 & 2 \\
\hline Part II - Total & 68 & 64 & 68 & 68 & 68 & $\mathbf{0}$ & 68 & $\mathbf{0}$ & 68 & 68 \\
\hline \multicolumn{11}{|l|}{ Part III: Performance } \\
\hline \multicolumn{11}{|l|}{ Indicators } \\
\hline Economic & 14 & 12 & 8 & 14 & 13 & 15 & 17 & 9 & 18 & 18 \\
\hline $\mathrm{EC} 1$ & 2 & 2 & 2 & 2 & 2 & 2 & 2 & 1 & 2 & 2 \\
\hline $\mathrm{EC} 2$ & 1 & 0 & 1 & 2 & 1 & 1 & 2 & 1 & 2 & 2 \\
\hline EC3 & 2 & 2 & 1 & 2 & 1 & 2 & 1 & 1 & 2 & 2 \\
\hline EC4 & 2 & 2 & 0 & 2 & 1 & 2 & 2 & 1 & 2 & 2 \\
\hline EC5 & 2 & 2 & 1 & 0 & 2 & 2 & 2 & 0 & 2 & 2 \\
\hline EC6 & 1 & 2 & 0 & 1 & 1 & 2 & 2 & 1 & 2 & 2 \\
\hline EC7 & 1 & 1 & 1 & 1 & 2 & 2 & 2 & 0 & 2 & 2 \\
\hline EC8 & 2 & 1 & 1 & 2 & 2 & 1 & 2 & 2 & 2 & 2 \\
\hline EC9 & 1 & 0 & 1 & 2 & 1 & 1 & 2 & 2 & 2 & 2 \\
\hline Environmental & 49 & 28 & 21 & 25 & 55 & 33 & 43 & 9 & 48 & 60 \\
\hline EN1 & 2 & 2 & 0 & 0 & 2 & 0 & 2 & 0 & 2 & 2 \\
\hline EN2 & 2 & 2 & 0 & 0 & 1 & 1 & 2 & 0 & 2 & 2 \\
\hline EN3 & 2 & 2 & 0 & 2 & 2 & 0 & 2 & 0 & 2 & 2 \\
\hline
\end{tabular}




\begin{tabular}{|c|c|c|c|c|c|c|c|c|c|c|}
\hline EN4 & 2 & 2 & 0 & 0 & 1 & 0 & 2 & 0 & 2 & 2 \\
\hline EN5 & 2 & 2 & 2 & 2 & 2 & 2 & 2 & 1 & 2 & 2 \\
\hline EN6 & 2 & 0 & 2 & 1 & 2 & 2 & 1 & 0 & 2 & 2 \\
\hline EN7 & 2 & 0 & 1 & 1 & 2 & 1 & 1 & 0 & 2 & 2 \\
\hline EN8 & 2 & 2 & 2 & 1 & 2 & 2 & 2 & 1 & 2 & 2 \\
\hline EN9 & 0 & 0 & 0 & 1 & 2 & 2 & 2 & 0 & 2 & 2 \\
\hline EN10 & 0 & 0 & 2 & 1 & 2 & 2 & 0 & 1 & 2 & 2 \\
\hline EN11 & 2 & 2 & 2 & 2 & 2 & 2 & 2 & 0 & 2 & 2 \\
\hline EN12 & 2 & 2 & 0 & 0 & 2 & 0 & 0 & 0 & 2 & 2 \\
\hline EN13 & 2 & 0 & 2 & 0 & 2 & 1 & 0 & 0 & 2 & 2 \\
\hline EN14 & 2 & 2 & 0 & 0 & 2 & 0 & 2 & 0 & 1 & 2 \\
\hline EN15 & 2 & 0 & 0 & 0 & 2 & 0 & 9 & 0 & 1 & 2 \\
\hline EN16 & 2 & 2 & 0 & 1 & 2 & 0 & 2 & 0 & 1 & 2 \\
\hline EN17 & 2 & 0 & 0 & 0 & 2 & 0 & 1 & 0 & 1 & 2 \\
\hline EN18 & 2 & 2 & 2 & 1 & 2 & 2 & 2 & 1 & 1 & 2 \\
\hline EN19 & 0 & 0 & 0 & 0 & 2 & 2 & 0 & 0 & 1 & 2 \\
\hline EN20 & 1 & 2 & 1 & 1 & 2 & 0 & 0 & 1 & 1 & 2 \\
\hline EN21 & 2 & 0 & 1 & 2 & 2 & 1 & 2 & 2 & 1 & 2 \\
\hline EN22 & 1 & 2 & 1 & 1 & 2 & 2 & 0 & 1 & 1 & 2 \\
\hline EN23 & 2 & 0 & 0 & 2 & 2 & 2 & 0 & 0 & 1 & 2 \\
\hline EN24 & 0 & 0 & 0 & 0 & 2 & 1 & 0 & 0 & 1 & 2 \\
\hline EN25 & 2 & 0 & 0 & 0 & 2 & 2 & 2 & 0 & 1 & 2 \\
\hline EN26 & 2 & 0 & 2 & 2 & 2 & 2 & 2 & 1 & 2 & 2 \\
\hline EN27 & 1 & 0 & 0 & 1 & 1 & 1 & 1 & 0 & 2 & 2 \\
\hline EN28 & 2 & 0 & 0 & 2 & 1 & 2 & 0 & 0 & 2 & 2 \\
\hline EN29 & 2 & 0 & 0 & 1 & 1 & 0 & 1 & 0 & 2 & 2 \\
\hline EN30 & 2 & 2 & 1 & 0 & 2 & 1 & 1 & 0 & 2 & 2 \\
\hline $\begin{array}{l}\text { Labor Practices and } \\
\text { Decent Work }\end{array}$ & 22 & 24 & 17 & 21 & 26 & 25 & 19 & 15 & 28 & 28 \\
\hline LA1 & 2 & 2 & 2 & 2 & 2 & 2 & 1 & 1 & 2 & 2 \\
\hline LA2 & 0 & 1 & 0 & 2 & 2 & 1 & 1 & 1 & 2 & 2 \\
\hline LA3 & 2 & 2 & 0 & 2 & 2 & 2 & 2 & 2 & 2 & 2 \\
\hline LA4 & 2 & 2 & 2 & 2 & 2 & 2 & 2 & 0 & 2 & 2 \\
\hline LA5 & 2 & 1 & 2 & 2 & 2 & 2 & 2 & 2 & 2 & 2 \\
\hline LA6 & 1 & 2 & 2 & 1 & 2 & 2 & 2 & 0 & 2 & 2 \\
\hline LA7 & 2 & 2 & 0 & 2 & 1 & 2 & 1 & 0 & 2 & 2 \\
\hline LA8 & 1 & 1 & 1 & 1 & 2 & 1 & 0 & 2 & 2 & 2 \\
\hline LA9 & 0 & 2 & 1 & 2 & 2 & 2 & 0 & 0 & 2 & 2 \\
\hline LA10 & 2 & 1 & 2 & 2 & 2 & 2 & 1 & 1 & 2 & 2 \\
\hline LA11 & 2 & 2 & 1 & 1 & 2 & 1 & 2 & 1 & 2 & 2 \\
\hline LA12 & 2 & 2 & 2 & 1 & 2 & 2 & 1 & 2 & 2 & 2 \\
\hline LA13 & 2 & 2 & 0 & 1 & 1 & 2 & 2 & 1 & 2 & 2 \\
\hline LA14 & 2 & 2 & 2 & 0 & 2 & 2 & 2 & 2 & 2 & 2 \\
\hline Human Rights & 10 & 14 & 9 & 8 & 14 & 13 & 12 & 7 & 18 & 18 \\
\hline HR1 & 1 & 1 & 0 & 0 & 1 & 1 & 0 & 0 & 2 & 2 \\
\hline HR2 & 1 & 1 & 1 & 0 & 1 & 1 & 0 & 0 & 2 & 2 \\
\hline HR3 & 1 & 0 & 0 & 0 & 2 & 0 & 2 & 0 & 2 & 2 \\
\hline HR4 & 1 & 2 & 2 & 2 & 2 & 2 & 2 & 2 & 2 & 2 \\
\hline HR5 & 2 & 2 & 2 & 2 & 2 & 2 & 2 & 1 & 2 & 2 \\
\hline HR6 & 2 & 2 & 2 & 2 & 2 & 1 & 2 & 2 & 2 & 2 \\
\hline HR7 & 2 & 2 & 2 & 2 & 2 & 2 & 2 & 2 & 2 & 2 \\
\hline HR8 & 0 & 2 & 0 & 0 & 2 & 2 & 2 & 0 & 2 & 2 \\
\hline HR9 & 0 & 2 & 0 & 0 & 0 & 2 & 0 & 0 & 2 & 2 \\
\hline Society & 10 & 10 & 6 & 7 & 5 & 13 & 10 & 7 & 16 & 16 \\
\hline $\mathrm{SO} 1$ & 1 & 0 & 1 & 0 & 2 & 1 & 1 & 0 & 2 & 2 \\
\hline $\mathrm{SO} 2$ & 1 & 0 & 1 & 1 & 1 & 2 & 1 & 2 & 2 & 2 \\
\hline
\end{tabular}




\begin{tabular}{|c|c|c|c|c|c|c|c|c|c|c|}
\hline $\mathrm{SO} 3$ & 2 & 2 & 1 & 0 & 0 & 1 & 0 & 1 & 2 & 2 \\
\hline $\mathrm{SO} 4$ & 2 & 0 & 1 & 0 & 0 & 1 & 2 & 2 & 2 & 2 \\
\hline SO5 & 0 & 2 & 0 & 2 & 0 & 2 & 2 & 2 & 2 & 2 \\
\hline SO6 & 0 & 2 & 2 & 2 & 2 & 2 & 2 & 0 & 2 & 2 \\
\hline SO7 & 2 & 2 & 0 & 2 & 0 & 2 & 0 & 0 & 2 & 2 \\
\hline SO8 & 2 & 2 & 0 & 0 & 0 & 2 & 2 & 0 & 2 & 2 \\
\hline Product Responsibility & 17 & 16 & 3 & 18 & 6 & 16 & 13 & 9 & 18 & 18 \\
\hline PR1 & 1 & 0 & 0 & 2 & 1 & 1 & 0 & 0 & 2 & 2 \\
\hline PR2 & 2 & 2 & 0 & 2 & 0 & 2 & 2 & 0 & 2 & 2 \\
\hline PR3 & 2 & 2 & 1 & 2 & 2 & 2 & 2 & 2 & 2 & 2 \\
\hline PR4 & 2 & 2 & 0 & 2 & 0 & 2 & 2 & 2 & 2 & 2 \\
\hline PR5 & 2 & 2 & 2 & 2 & 1 & 2 & 1 & 2 & 2 & 2 \\
\hline PR6 & 2 & 2 & 0 & 2 & 2 & 1 & 2 & 1 & 2 & 2 \\
\hline PR7 & 2 & 2 & 0 & 2 & 0 & 2 & 2 & 2 & 2 & 2 \\
\hline PR8 & 2 & 2 & 0 & 2 & 0 & 2 & 2 & 0 & 2 & 2 \\
\hline PR9 & 2 & 2 & 0 & 2 & 0 & 2 & 0 & 0 & 2 & 2 \\
\hline Part III -Total & 122 & 104 & 64 & 93 & 119 & 115 & 114 & 56 & 146 & 158 \\
\hline TOTAL & 274 & 252 & 216 & 245 & 271 & 199 & 266 & 114 & 298 & 310 \\
\hline
\end{tabular}

